\title{
THE CORRELATION BETWEEN THERAPEUTIC COMMUNICATION AND THE ANXIETY OF PRE- OPERATED PATIENT AT FLAMBOYAN WARD PUSRI HOSPITAL PALEMBANG 2016
}

\author{
Tafdhila $^{1}$, Siti Revisia ${ }^{2}$ \\ 1. Dosen STIK Siti Khadijah Palembang
}

\begin{abstract}
Therapeutic communication and realtion which connected between nurse and patient could decrease the anxiety because the patient can explore their feeling, tell their anxiety to face the situation and got the solution. Based on the interview to 6 patients at Flamboyan ward Pusri Hospital Palembang, it was found that they feel anxious about painful after operation, physical change, and unsuccessful operation. The aim of this study was to find out the correlation between therapeutic communication and anxiety of pre-operated patient at Flamboyan ward Pusri hospital Palembang in 2016.This study was done from April 11-30 2016. The quantitative through cross sectional design was used in this study. The populastion of the study was all pre-operated patient at Flamboyan ward Pusri hospital Palembang. The accidental sampling technique was used to select the sample. The total number of the sample was 30 respondents. The univariate and bivariate analysis was used to analyze the data. The result of the study showed that there was a correlation between therapeutic communication and anxiety with $\rho$-value $0,030<0,05$. Finally, it is hoped that hospital stakeholders could conduct some trainings for therapeutic communication skill for the nurse to add their skill as one of standard operational before having an operation.
\end{abstract}

References $\quad: 28(2002-2015)$

Keywords : Therapeutic Communication, Anxiety, Pre-Operative 


\section{Pendahuluan}

Tindakan pembedahan (operasi) merupakan salah satu bentuk terapi dan merupakan upaya yang dapat mendatangkan ancaman terhadap tubuh. Tindakan pembedahan yang direncanakan dapat menimbulkan respon fisiologis dan psikologis pada pasien. Rentang respon akibat pembedahan tergantung pada individu, pengalaman masa lalu, pola koping, kekuatan dan keterbatasan. Salah satunya asuhan keperawatan yang komprehensifdiberikan pada pasien pre operasi yang dilakukan sebelum pembedahan (Atmawati, 2010).

Perawatan pre operasi dimulai ketika keputusan untuk intervensi bedah dibuat

dan berakhir saat pasien dikirim ke meja operasi. Perawatan pre operasi yang efektif dapat mengurangi resiko post operasi, salah satu prioritas keperawatan pada periode ini adalah mengurangi kecemasan pasien (Smeltzer \& Bare, 2002 dalam Arbani 2015). Alasan yang dapat menyebabkan ketakutan atau kecemasan pasien dalam menghadapi pembedahan antara lain adalah takut nyeri setelah pembedahan, takut terjadi perubahan fisik, dan takut operasi akan gagal (Potter \& Perry, 2005 dalam Arbani 2015). Suatu penelitian menyebutkan bahwa80\%dari pasien yang akanmenjalani pembedahan akan mengalami kecemasan (Atmawati, 2010). Maka tidak heran jika pasien dan keluarga sering menunjukkan sikap yang berlebihan dengan kecemasan yang dialaminya.

Kecemasan tersebut dimani festasikan secara langsung melalui perubahan fisiologis seperti (gemetar, berkeringat, detak jantung meningkat, nyeri abdomen, sesak nafas) dan perubahan perilaku seperti (gelisah, bicara cepat, reaksi terkejut) dan secara tidak langsung melalui timbulnya gejala sebagai upaya untuk melawan kecemasan (Stuart \& Laraia, 2005 dalam Arbani 2015). Salah satu faktor yang mempengaruhi kecemasan adalah pandangan interpersonal yang beranggapan adanya ancaman terhadap integritas fisik meliputi disabilitas fisiologis yang akan terjadi atau penurunan kemampuan untuk melakukan aktivitas sehari-hari (Stuart, 2006).

Berdasarkan hasil penelitian dari beberapa peneliti diberbagai rumah sakit di Indonesia yang di posting di situs resmi internet, diketahui berbagai hal penting mengenai angka kejadian kecemasan pada pasien pre operatif. Menurut Atmawati (2010), tingkat kecemasan Pasien Pre Operatif di RSUD Setjonegoro Kabupaten Wonosobo yaitu sekitar 84,4\% dominan kategori ringan. Berdasarkan hasil penelitian yang dilakukan oleh Uskenat, dkk (2011), didapatkan tingkat kecemasan $40 \%$ pasien memiliki hasil tingkat kecemasan dominan kategori sedang, dan 3,3\% pasien memiliki tingkat kecemasan kategori berat. Berdasarkan penelitian yang dilakukan oleh Arbani 
(2015), bahwa tingkat kecemasan pada pasien pre operasi di RS PKU Muhammadiyah Sukoharjo dominan kategori ringan yaitu sebesar 56,7 \%. Hal ini menunjukkan sebagian besar pasien pre operasi mengalami kecemasan.

Komunikasi dan hubungan terapeutik yang terbina antara perawat dan klien dapat membantu menurunkan kecemasan klien karena klien dapat mengeksplorasikan perasaannya, menceritakan ketakutan, kekhawatirannya menghadapi situasi tersebut dan mendapatkan solusi serta pengetahuan yang diperlukan (Nasir, 2009). Salah satu cara untuk menurunkan kecemasan adalah dengan komunikasi yang baik. Dalam penelitian Mulyani (2008), membuktikan bahwa penurunan kecemasan pada pasien pre operasi dengan komunikasi dan hubungan terapeutik antara perawat-klien mampu menurunkan kecemasan klien.

Perawat sebagai anggota inti tenaga kesehatan yang jumlahnya terbesar di rumah sakit memiliki peran kunci dalam mewujudkan kesembuhan pasien. Perawat sebagai petugas kesehatan yang selalu berhubungan langsung dengan pasien harus memiliki keterampilan berkomunikasi dengan pasien sehingga mudah menjalani hubungan saling percaya dengan pasien, mencegah terjadinya masalah ilegal, memberi kenyamanan dalam pelayanan keperawatan dan meningkatkan citra profesi keperawatan serta citra rumah sakit (Mubarak, 2009).

Sebagai suatu institusi yang memberikan pelayanan kesehatan RS
Pusri Palembang yang terletak di Provinsi Sumatera Selatan. Berdasarkan data rekam medik di Ruang Flamboyan RS Pusri Palembang, pasien yang telah melakukan operasi pada tahun 2014 sebanyak 695 orang pasien. Pada tahun 2015 sebanyak 718 orang pasien. Sementara pada data yang diperoleh 2 bulan terakhir Januari sampai Februari 2016 sebanyak 114 orang pasien.

Berdasarkan studi pendahuluan yang peneliti lakukan pada tanggal 1114 Maret 2016 di Ruang Flamboyan RS Pusri Palembang di dapatkan 6 pasien pre operasi , 4 pasien (66\%) mengalami cemas ringan, 1 pasien (17\%) pasien mengalami cemas sedang, dan 1 pasien (17\%) mengalami cemas berat.Dari hasil studi pendahuluan yang peneliti lakukan pada tanggal 11-14 Maret 2016 di Ruang Flamboyan RS Pusri Palembang terhadap 6 orang pasien tentang komunikasi terapeutik yang dilakukan oleh perawat, didapatkan $66 \%$ perawat cukup baik dalam pemberian informasi terhadap segala prosedur tindakan yang dilakukan.

Berdasarkan fenomena diatas maka peneliti tertarik untuk meneliti hubungan komunikasi terapeutik perawat dengan tingkat kecemasan pasien pre operasi di Ruang Flamboyan RS Pusri Palembang.

\section{Metode Penelitian}

Jenis penelitian ini adalah kuantitativ dengan menggunakan pendekatan Survey Analitik dengan rancangan Cross sectional. Rancangan Cross Sectional adalah suatu penelitian 
yang menekankan waktu/pengukuran observasi data variabel independen dan dependen hanya satu kali pada satu saat (Nursalam, 2011).

Populasi dalam penelitian ini adalah pasien pre operasi di Ruang Flamboyan di RS Pusri Palembang, dengan teknik pengambilan sampel dilakukan secara Accidental Sampling. Penelitian ini dilakukan pada tanggal 11-30 April 2016 dengan sampel yang didapat adalah 30 responden.

Instrument dalam penelitian ini menggunakan lembaran kuesioner yang berkaitan dengan komunikasi terapeutik dan tingkat kecemasan pre pre operasi. Untuk komunikasi terapeutik berupa 19 pernyataan yang diberi skor apabila 1=tidak pernah, 2=kadang-kadang, 3 selalu. Dari ke-19 pernyataan tersebut dijumlahkan dengan total nilai apabila $>44$ :kategori baik dan $<44$ kategori cukup.

Kuesioner tingkat kecemasan menggunakan HARS (Hamilton Anxiety Rate Scale) berupa 14 kelompok gejala yang diberi score 0-4 yang artinya nilai 0 : tidak ada kecemasan, 1: kecemasan ringan, 2:kecemasan sedang, 3:kecemasan berat, 4:kecemasan sangat berat. Dari ke-14 kelompok gejala dijumlahkan dengan total nilai score yaitu skor $<6$ : tidak ada kecemasan, 7-14:kecemasan ringan, 15-27:kecemasan sedang, $>27$ :kecemasan berat.

Pengolahan data dilakukan dengan tahap pengumpulan data(Editing), Pengkodean(Coding), memasukkan data(Data Entry) dan pembersihan data (Cleaning Data)/

Analisis yang digunakan dalam penelitian ini adalah analisis univariat untuk mengetahui distribusi frekuensi komunikasi terapeutik, tingkat kecemasan.

Analisis bivariat untuk mengetahui hubungan antara dua variabel yaitu variabel independen (komunikasi terapeutik) dan variabel dependen (tingkat kecemasan) menggunakan uji statistik Chi-Squaredengan keputusan bermakna bila $\rho$-value dengan $\alpha=0,05$ dengan ketentuan: ada hubungan antara variabel independen dan dependen, jika $\rho$ value $<\alpha(0,05)$ dan Tidak ada hubungan antara variabel independen dan variabel dependen, jika $\rho$ value $>\alpha(0,05)$.

\section{Hasil penelitian \\ Analisis Univariat}

\section{Komunikasi Terapeutik}

Tabel 5.1

Distribusi Frekuensi Responden Berdasarkan Komunikasi Terapeutik

Di Ruang Flamboyan RS Pusri Palembang Tahun 2016

\begin{tabular}{llll}
\hline No & $\begin{array}{l}\text { Komunikasi } \\
\text { teraupetik }\end{array}$ & $\begin{array}{l}\text { Jumlah } \\
(\mathbf{n})\end{array}$ & $\begin{array}{l}\text { Persentasi } \\
(\%)\end{array}$ \\
\hline 1 & Baik & 18 & 60 \\
2 & Cukup & 12 & 40 \\
& Jumlah & 30 & 100 \\
\hline
\end{tabular}

Berdasarkan Tabel 5.1 diatas
dari $30 \quad$ responden didapatkan
responden yang
komunikasi terapeutik baik berjumlah
18 responden $(60 \%)$, lebih banyak
dibandingkan responden yang
memberikan komunikasi terapeutik


cukup yaitu berjumlah 12 responden (40\%).

2.Tingkat Kecemasan

Tabel 5.2

Distribusi Frekuensi Responden

Berdasarkan Tingkat Kecemasan

Di Ruang Flamboyan RS Pusri palembang Tahun 2016

\begin{tabular}{llll}
\hline No & $\begin{array}{l}\text { Tingkat } \\
\text { Kecemasan }\end{array}$ & $\begin{array}{l}\text { Jumlah } \\
(\mathbf{n})\end{array}$ & $\begin{array}{l}\text { Persentasi } \\
(\mathbf{\%})\end{array}$ \\
\hline $\mathbf{1}$ & Ringan & 16 & 53,3 \\
$\mathbf{2}$ & Berat & 14 & 46,7 \\
& Jumlah & 30 & 100 \\
\hline
\end{tabular}

\begin{abstract}
Berdasarkan Tabel 5.2 diatas
dari 30 responden didapatkan responden yang mempunyai tingkat kecemasan ringan berjumlah 16 responden (53,3\%), lebih banyak dibandingkan responden dengan tingkat kecemasan berat berjumlah 14 responden $(46,7 \%)$.
\end{abstract}

\section{Analisis Bivariat}

Hubungan Komunikasi Terapeutik dengan Tingkat Kecemasan

Tabel 5.3

Hubungan Komunikasi Terapeutik dengan Tingkat Kecemasan Pasien Pre Operasi Di Ruang Flamboyan RS Pusri Palembang Tahun 2016

\begin{tabular}{|c|c|c|c|c|c|c|c|c|}
\hline \multirow{3}{*}{$\begin{array}{l}\mathbf{N} \\
\mathbf{0}\end{array}$} & \multirow{3}{*}{$\begin{array}{l}\text { Kamunikasi } \\
\text { teraupetik }\end{array}$} & \multicolumn{4}{|c|}{ Tingkat kecemasan } & \multicolumn{2}{|c|}{ Jumlah } & \multirow{3}{*}{$\begin{array}{l}P \\
\text { (value) }\end{array}$} \\
\hline & & \multicolumn{2}{|c|}{ Ringan } & \multicolumn{2}{|c|}{ Berat } & & & \\
\hline & & $\mathbf{n}$ & $\%$ & $\mathbf{n}$ & $\%$ & $\mathbf{n}$ & $\%$ & \\
\hline 1 & Baik & 13 & 72 & 5 & 28 & 18 & $\overline{100}$ & 0,03 \\
\hline \multirow[t]{2}{*}{2} & Cukup & 3 & 25 & 9 & 75 & 12 & 100 & \\
\hline & Jumlah & 16 & 53 & 14 & 47 & 30 & 100 & \\
\hline
\end{tabular}

Berdasarkan Tabel 5.3 diatas didapatkan responden yang mempunyai komunikasi terapeutik baik dengan tingkat kecemasan ringan berjumlah 13 responden $(72,2 \%)$ dari 18 responden, lebih banyak dibandingkan responden yang mempunyai komunikasi terapeutik cukup dengan tingkat kecemasan ringan berjumlah 3 responden (25\%) dari 12 responden.

berdasarkan hasil uji statistic Chi-Square didapatkan $\rho$-value $=$ $0,030<\alpha(0,05)$ maka (Ho ditolak). Dari hasil tersebut bisa diambil kesimpulan bahwa ada hubungan yang bermakna antara komunikasi terapeutik dengan tingkat kecemasan pasien pre operasi di Ruang Flamboyang RS Pusri Palembang Tahun 2016.

\section{Pembahasan Univariat}

1.Komunikasi Terapeutik

Dari hasil analisis univariat pada variabel komunikasi terapeutik menunjukkan dari 30 responden didapatkan responden yang memberikan komunikasi terapeutik baik berjumlah 18 responden (60\%), lebih banyak dibandingkan responden yang memberikan komunikasi terapeutik cukup yaitu berjumlah 12 responden $(40 \%)$.

Menurut Ina \& Wahyu (2010), komunikasi terapeutik merupakan komunikasi yang direncanakan secara 
sadar, tujuan dan kegiatannya difokuskan. Menurut Setiowati (2012), komunikasi terapeutik dikatakan baik apabila perawat bekerja sama dengan pasien mendiskusikan tentang masalah yang sedang dihadapi untuk pencapaian tujuan tindakan keperawatan, perawat memberi informasi tentang tindakan keperawatan yang akan dilakukan dan mengevaluasi hasil tindakan keperawatan terhadap pasien.

Hasil penelitian Arbani (2015), didapatkan analisis univariat responden dengan komunikasi terapeutik baik berjumlah 20 responden (66,7\%) lebih besar dibandingkan responden yang komunikasi terapeutiknya cukup 10 responden $(33,3 \%)$.

Berdasarkan hasil penelitian, teori dan penelitian terkait peneliti berpendapat bahwa komunikasi terapeutik yang dilakukan perawat kepada pasien sangat mempengaruhi pemahaman pasien terhadap asuhan keperawatan yang diberikan. Karena komunikasi terapeutik salah satu cara yang dapat digunakan untuk perawat dalam memberikan hubungan saling percaya antara pasien dengan perawat.

\section{Tingkat kecemasan}

Dari hasil analisis univariat pada variabel tingkat kecemasan menunjukkan dari 30 responden didapatkan responden yang mempunyai tingkat kecemasan ringan berjumlah 16 responden (53,3\%), lebih banyak dibandingkan responden dengan tingkat kecemasan berat berjumlah 14 responden (46,7\%) .
Menurut Agustin,I.M (2009), kecemasan terjadi karena cemas dijadikan sebagai stressor yang merupakan perasaan takut seseorang terhadap suatu keadaan yang tidak menyenangkan yang secara subjektif di alami dan dikomunikasikan secara interpersonal. Manifestasi kecemasan yang dapat muncul seperti sulit tidur, dada berdebar, tubuh berkeringat meskipun tidak gerah, tubuh panas atau dingin, sakit kepala, otot tegang atau kaku, sakit perut, terengah-engah atau sesak nafas (smeltzer \& Bare, 2002).

Menurut Baradero (2008) yang menyatakan bahwa operasi akan mengakibatkan rasa cemas karena kaitan dengan takut akan sesuatu yang belum diketahui, nyeri, perubahan citra tubuh, perubahan fungsi tubuh, kehilangan kendali, dan kematian.

Hasil penelitian Arbani (2015), analisis univariat responden didapatkan responden yang memiliki kecemasan ringan berjumlah 17 responden $(56,7 \%)$ lebih besar dibandingkan responden yang tidak memiliki kecemasan yaitu berjumlah 13 responden $(43,3 \%)$.

Dari hasil penelitian lain Arifah (2012) menunjukan bahwa kecemasan ringan sebanyak 21 responden $(52,5 \%)$ lebih besar dibandingkan responden yang memiliki kecemasan sedang 12 responden $(30 \%)$, kecemasan berat 7 responden $(17,5 \%)$.

$\begin{array}{ccr}\text { Hasil } & \text { penelitian } & \text { Atmawati } \\ \text { (2010), } & \text { menunjukkan } & \text { bahwa }\end{array}$ responden yang mengalami kecemasan ringan berjumlah 38 responden (84,4\%), lebih besar dibandingkan responden yang mengalami kecemasan 
sedang berjumlah 7 responden $(15,6 \%)$.

Berdasarkan hasil penelitian, teori dan penelitian terkait peneliti berpendapat bahwa kecemasan ringan yang dialami responden lebih banyak karena responden percaya tindakan operasi yang dilakukan semata-semata untuk penyembuhan. Ketakutan berlebihan dan fokus akan setelah operasi menyebabkan responden mengalami kecemasan berat.

\section{Pembahasan Bivariat}

\section{Hubungan Komunikasi Terapeutik dengan Tingkat Kecemasan}

Hasil penelitian yang dilakukan di Ruang Flamboyan RS Pusri Palembang tahun 2016 terhadap 30 responden didapatkan responden yang mempunyai komunikasi terapeutik baik dengan tingkat kecemasan ringan berjumlah 13 responden $(72,2 \%)$ dari 18 responden, lebih banyak dibandingkan responden yang mempunyai komunikasi terapeutik cukup dengan tingkat kecemasan ringan berjumlah 3 responden (25\%) dari 12 responden. Dari hasil uji chi square didapatkan bahwa $p$ value $=$ 0,030 lebih kecil dari $\alpha=0,05$. Hal ini menunjukkan ada hubungan yang signifikan antara komunikasi terapeutik dengan tingkat kecemasan pasien pre operasi di Ruang Flamboyan RS Pusri Palembang. Menurut Soesanto dan Nurkholis (2008), bahwa komunikasi merupakan hal yang sangat penting dalam proses pemberian asuhan keperawatan. Komunikasi yang terjalin baik akan menimbulkan rasa kepercayaan sehingga terjadi hubungan yang hangat dan mendalam. Tujuan komunikasi terapeutik adalah membantu pasien untuk memperjelas, mengurangi beban perasaan dan pikiran serta dapat mengambil tindakan untuk mengubah situasi yang ada bila pasien percaya pada hal yang diperlukan.

Menurut Dewi (2007), untuk mengurangi kecemasan dan ketakutan pasien perlu ditekankan bahwa kesan lahiriah perawat mampu berbicara banyak, baik mulai profil tubuh atau wajah terutama senyum yang tulus dari perawat, kerapian berbusana, sikap familiar dan yang paling penting cara berbicara.

Berdasarkan Mulyani (2008) bahwa komunikasi dan hubungan terapeutik perawat dan klien mampu menurunkan kecemasan klien. Komunikasi dan hubungan terapeutik yang terbina antara perawat dan klien dapat membantu menurunkan kecemasan klien karena klien dapat mengeksplorasikan perasaannya, menceritakan ketakutan, kekhawatirannya menghadapi situasi tersebut dan mendapatkan solusi serta pengetahuan yang diperlukan.

Berdasarkan Penelitian Arbani (2015) tentang "Hubungan komunikasi Terapeutik dengan Tingkat Kecemasan Pasien Pre operasi di RS PKU Muhammadiyah Sukoharjo" dengan jumlah sampel sebanyak 30 responden didapatkan, dari 20 responden yang memiliki komunikasi terapeutik baik dan tidak mengalami kecemasan berjumlah 12 responden (40\%), yang komunikaasi terapeutik cukup dan 
tidak memiliki kecemasan berjumlah 1 responden $(3,3 \%)$ dari 10 responden. Dengan nilai $\mathrm{p}(0,009)<\alpha=0,05$ yang berarti ada hubungan antara komunikasi terapeutik dengan tingkat kecemasan.

Berdasarkan penelitian Atmawati (2010) dengan judul "Hubungan Komunikasi Terapeutik Perawat dengan Tingkat Kecemasan Pasien pre operasi di RSUD Setjonrgoro Kabupaten Wonosobo" dengan jumlah sampel 45 orang didapatkan, sebagian besar responden yang mengalami kecemasan ringan dan komunikasi terapeutik baik yaitu sebanyak 25 responden (55,6\%) sedangkan responden yang paling sedikit mengalami kecemasan sedang dan komunikasi terapeutik cukup sebanyak 7 responden $(15,6 \%)$, dengan nilai $p$ value $(0,001)<\alpha=0,05$ sehingga dapat disimpulkan ada hubugan antara komunikasi terapeutik perawat dan tingkat kecemasan.

Berdasarkan hasil penelitian, teori dan penelitian terkait peneliti berpendapat bahwa semakin baik komunikasi perawat maka semakin ringan kecemasan yang terjadi pada pasien sebelum operasi. Bahasa, Sikap maupun intonasi yang diberikan saat berkomunikasi dengan pasien mampu dimengerti sehingga tingkat kecemasan yang dialamipun tergolong ringan. Hal ini dengan adanya komunikasi terapeutik pasien bisa mendapatkan informasi dan mengerti mengenai tindakan operasi yang dilakukan pada dirinya sehingga bisa mengurangi kecemasan pada diri pasien saat sebelum dilakukan operasi.

\section{Kesimpulan}

Dari hasil penelitian yang peneliti lakukan terhadap 30 responden tentang hubungan komunikasi terapeutik dengan tingkat kecemasan pasien pre operasi di Ruang Flamboyan RS Pusri Palembang Tahun 2016 maka didapatkan kesimpulan sebagai berikut

1. Distribusi frekuensi komunikasi terapeutik pada pasien pre operasi di Ruang Flamboyan RS Pusri Palembang sebagian besar baik yaitu sebanyak 18 responden $(60 \%)$ dari 30 responden.

2. Distribusi frekuensi tingkat kecemasan pasien pre operasi di Ruang Flamboyan RS Pusri Palembang sebagian besar ringan yaitu sebanyak 16 responden $(53,3 \%)$ dari 30 responden.

3. Ada hubungan yang signifikan antara komunikasi terapeutik dengan tingkat kecemasan pasien pre operasi di Ruang Flamboyan RS Pusri Palembang dengan $p$ value 0,030 .

\section{Saran}

Diharapkan bagi pihak rumah sakit untuk mengadakan kegiatan pelatihan dalam penerapan komunikasi terapeutik bagi para perawat dan menambahkan komunikasi terapeutik sebagai salah satu SOP untuk pasien sebelum operasi. 


\section{Daftar Pustaka}

Agustin,I.M (2009).Hubungan
Pelaksanaan Komunikasi
Terapeutik Dengan Tingkat
Kecemasan Pasien Rawat Inap
di BP RSUD Kabumen. Ilmiah
Kesehatan Keperawatan.5.143-
152.
Arbani, A.2015.Hubungan
Komunikasi Terapeutik dengan
Tingkat Kecemasan Pasien Pre
Operasi di RS PKU
Muhammadiyah
Sukoharjo.Jurnal.

Arifah.2012.Pengaruh Pemberian

Informasi Tentang Persiapan

Operasi Dengan Pendekatan

Komunikasi Terapeutik

Terhadap Tingkat Kecemasan

Pasien Pre Operasi di Ruang

Bougenville RSUD

Sleman.Jurnal

Kebidanan.IV,140-219.

Atmawati.2010.Hubungan

Komunikasi Terapeutik

Perawat dengan Tingkat

Kecemasan Pasien Pre

Operasi di RSUD Setjonegoro

Kabupaten Wonosobo.Jurnal.

Baradero,M.2008.Keperawatan

Perioperatif :Prinsip dan

Praktik.Jakarta:EGC.

Damayanti.2008.Komunikasi

Terapeutik dalam praktik

keperawatan.Jakarta:Refika

Aditama.

Hawari.2008.Manajemen Stress

Cemas

dan
Hidayat,A.A.2007.Komunikasi

Terapeutik

Keperawatan.Jakarta:Salemba

Medika

Ina,Wahyu.2010. Komunikasi

Terapeutik

Keperawatan. Yogyakarta.

Maryunani,A.2014.Asuhan

Keperawatan Perioperatif-Pre

Operasi (Menjelang

Pembedahan).Jakarta:TIM.

.2015.Asuhan Keperawatan

Intra Operasi di Kamar Bedah

(Selama

Pembedahan).Jakarta:TIM.

Mubarak,W,I.2009.Komunikasi Dalam

Keperawatan Teori dan

Aplikasi. Jakarta: Salemba

Medika.

Mulyani.2008.Komunikasi dan Hubungan Terapeutik Perawat-

Klien Terhadap Kecemasan

Pra Bedah Mayor. Jakarta

Musliha

Fatmawati.2009.Komunikasi

Keperawatan

Materi

Komunikasi

Terapeutik.Jakarta:Nuha

Medika.

Nasir,A.2009. Komunikasi Dalam

Keperawatan dan

Aplikasi.Jakarta:Salemba

Medika.

Nursalam.2011.Konsep dan

Penerapan Metedologi

Penelitian Ilmu Keperawatan.

Edisi 2.Jakarta:Salemba

Medika

2013.Konsep dan

Penerapan Metedologi

Penelitian Ilmu Keperawatan.

Edisi 3.Jakarta:Salemba

Medika. 
Potter \& Perry.2005.Buku Ajar Keperawatan Dasar. Edisi 4.Jakarta:EGC

Rosdahl,Caroline Bunker.2014.Buku Ajar Keperawatan Dasar. Edisi 10. Jakarta: EGC

Saryono.2011. Metode Penelitian Kebidanan DIII, DIV, Sldan $S 2$.Yogyakarta:Mitra Cendikia.

Sekolah Tinggi Ilmu Kesehatan Siti Khadijah

Palembang.2016.Panduan

Penulisan Skripsi:"Program Studi Ilmu

Keperawatan”.Sekolah Tinggi Ilmu Kesehatan Siti Khadijah Palembang.Palembang,Indones ia.

Setiowati.2012.Tahapan Komunikasi Terapeutik Perawat Terhadap Pasien RSI PKU Muhammadiyah Pekalongan.

Smeltzer.SC.bare,B.G.2002. Buku Ajar Keperawatan Medika Bedah (Terjemahan).Jakarta:EGC.

Soesanto,E,Nurkholis.2008.Hubungan Komunikasi Terapeutik Perawat Dengan Kecemasan
Pasien Gangguan

Kardiovaskuler Yang Pertama Kali diRawat di Intensive Coronary Care Unit RSU Tugurejo Semarang.Jurnal Keperawatan.Hal.1-11

Sugiyono.2007. Statistik untuk Penelitian. Bandung:Alfabeta.

Suliswati,dkk.2005.Konsep Dasar Keperawatan Jiwa. Jakarta:EGC.

Stuart,G.W.2006. Buku Saku Keperawatan Jiwa. Edisi 5. Jakarta:EGC.

Uskenat,dkk.2011. Hubungan Komunikasi Terapeutik dengan Tingkat Kecemasan Pasien Pre Operasi di RS PKU Muhammadiyah Sukoharjo.Jurnal.11-14 